\title{
Spatial and Temporal Assessment of Nitrate-N under Rice-Wheat System in Riparian Wetlands of Punjab, North-Western India
}

\author{
Bhupinder S. Farmaha ${ }^{1, *\left(\mathbb{C}, \text { Pritpal-Singh }^{2}(\mathbb{C}) \text { and Bijay-Singh }\right.}{ }^{3}(\mathbb{C}$ \\ 1 Edisto Research and Education Center, Department of Plant \& Environmental Sciences, Clemson University, \\ Blackville, SC 29817, USA \\ 2 Department of Soil Science, Punjab Agricultural University, Khokhar Khurd, District Mansa, \\ Punjab 151505, India; jasppsingh@gmail.com \\ 3 Department of Soil Science, Punjab Agricultural University, Ludhiana 141004, India; \\ bijaysingh20@hotmail.com \\ * Correspondence: bfarmah@clemson.edu; Tel.: +1-217-778-5170
}

Citation: Farmaha, B.S.

Pritpal-Singh; Bijay-Singh. Spatial and Temporal Assessment of Nitrate-N under Rice-Wheat System in Riparian Wetlands of Punjab, North-Western India. Agronomy 2021, 11, 1284. https://doi.org/10.3390/ agronomy 11071284

Academic Editor: Qi Jing

Received: 26 April 2021

Accepted: 19 June 2021

Published: 24 June 2021

Publisher's Note: MDPI stays neutral with regard to jurisdictional claims in published maps and institutional affiliations.

Copyright: (c) 2021 by the authors. Licensee MDPI, Basel, Switzerland. This article is an open access article distributed under the terms and conditions of the Creative Commons Attribution (CC BY) license (https:// creativecommons.org/licenses/by/ $4.0 /$ )
Abstract: The nitrate $\left(\mathrm{NO}_{3}{ }^{-}\right)$leaching assessment from extensive fertilizer nitrogen $(\mathrm{N})$ applications to croplands is crucial to optimize fertilizer- $\mathrm{N}$ recommendations that do not threaten the quality of drinking groundwater. SWAP (Soil Water Atmosphere Plant), a water balance model, was linked with ANIMO (Agricultural NItrogen MOdel), a nitrate leaching model and the Geographical Information System (GIS) to assess the spatial and temporal leaching of $\mathrm{NO}_{3}{ }^{-}-\mathrm{N}$ from fields under rice-wheat cropping system in the riparian wetlands in the Punjab in north-western India. The results revealed that $\mathrm{NO}_{3}{ }^{-}-\mathrm{N}$ concentration in the groundwater exceeded the $10 \mathrm{mg} \mathrm{NO}_{3}{ }^{-}-\mathrm{N} \mathrm{L}^{-1}$ limit set by the World Health Organization (WHO) for drinking water only during December-January. The verification of these results using measured values indicated that the SWAP-ANIMO model satisfactorily predicted $\mathrm{NO}_{3}{ }^{-}-\mathrm{N}$ concentrations in the leachate in the vadose zone. A low value of the mean absolute error (0.5-1.4) and a root mean square error (0.6-1.5) was observed between the measured and the predicted $\mathrm{NO}_{3}{ }^{-}-\mathrm{N}$ concentration across the soil profile during the validation at five sampling sites. The $\mathrm{NO}_{3}{ }^{-}-\mathrm{N}$ predictions revealed that in the long-term, the ongoing fertilizer- $\mathrm{N}$ management practices in the riparian wetlands will not significantly change the average $\mathrm{NO}_{3}{ }^{-}-\mathrm{N}^{-}$concentration in the groundwater. The modeling approach was satisfactory for an efficient quantitative assessment of $\mathrm{NO}_{3}{ }^{-}-\mathrm{N}$ pollution in groundwater while accounting for the spatial and temporal variability.

Keywords: ANIMO model; GIS; groundwater; nitrate leaching; spatial variability; riparian wetlands

\section{Introduction}

About $99 \%$ of the total 4.14 million ha (Mha) net sown area in the state of Punjab in north-western India is irrigated [1]. The irrigated wheat (November to April) and wetland rice (June to October) are grown in Punjab in annual rotation in deep alluvial soils with sandy loam and loamy sand as the dominant textures and containing less than $0.5 \%$ soil organic carbon (SOC). The recommended fertilizer nitrogen $(\mathrm{N})$ application rate for rice and wheat in Punjab is $120 \mathrm{~kg} \mathrm{~N} \mathrm{ha}^{-1}\left(240 \mathrm{~kg} \mathrm{~N} \mathrm{ha}^{-1}\right.$ for the annual rice-wheat cropping system), but this is hardly adopted. Farmers use between 130 and $195 \mathrm{~kg} \mathrm{~N} \mathrm{ha}^{-1}$ in rice and between 95 to $200 \mathrm{~kg} \mathrm{~N}$ ha $^{-1}$ in wheat [2].

Negligible losses of nitrate- $\mathrm{N}\left(\mathrm{NO}_{3}{ }^{-}-\mathrm{N}\right)$ beyond $200 \mathrm{~cm}$ depth have been recorded when ${ }^{15} \mathrm{~N}$-labelled potassium nitrate was applied as fertilizer during the wheat season [3]. However, the $\mathrm{N}$ remaining in the profile and that applied during the rice season is preferentially leached beyond the rooting zone because the crop of wetland rice receives about $150 \mathrm{~cm}$ irrigation and $33 \mathrm{~cm}$ of average annual rainfall, and a large fraction of the applied water percolates down through the soil profile. Due to high percolation rates, the soil under rice experiences alternating aerobic-anaerobic cycles that facilitate $\mathrm{NO}_{3}{ }^{-}-\mathrm{N}$ production, 
unlike in ideal rice soils. Therefore, the $\mathrm{NO}_{3}{ }^{-}-\mathrm{N}$ content in the groundwater in the Indian Punjab has been consistently increasing since 1975 when samples were analyzed for the first time [4,5]. Recent investigations of $\mathrm{NO}_{3}{ }^{-}-\mathrm{N}$ concentration in the groundwater of 14 intensively cultivated regions in the Punjab reported that 76 sites had $\mathrm{NO}_{3}{ }^{-}-\mathrm{N}$ concentrations in the range of 38.5 to $198.1 \mathrm{mg} \mathrm{NO}_{3}{ }^{-}-\mathrm{N} \mathrm{L}^{-1}$, and over $92 \%$ of sites showed a higher level than the safe limits given by the World Health Organization (50 $\mathrm{mg} \mathrm{NO}_{3}{ }^{-}-\mathrm{N} \mathrm{L}^{-1}$ ) and Bureau of Indian Standards $\left(45 \mathrm{mg} \mathrm{NO}_{3}{ }^{-}-\mathrm{N} \mathrm{L}^{-1}\right)$ [6]. Using remote sensing and Geographical Information System (GIS) based approach to collect data on fertilizer-N use, soil properties and rainfall at $1-\mathrm{km}^{2}$ grid size, and $\mathrm{N}$ loss coefficients derived from published $\mathrm{N}$ dynamics studies revealed that approximately $29 \%$ of the applied fertilizer- $\mathrm{N}$ to rice is lost as $\mathrm{NO}_{3}{ }^{-}-\mathrm{N}$ in the coarse textured soils of north-western India [7]. The weighted average $\mathrm{NO}_{3}{ }^{-}-\mathrm{N}$ loss via leaching was estimated to be more than $50 \mathrm{~kg} \mathrm{ha}^{-1}$ a year $^{-1}$ [7].

The identification of high $\mathrm{NO}_{3}{ }^{-}-\mathrm{N}$ zones in the groundwater can be useful to policymakers for analyzing and comparing with the present situation and for making realistic estimates and making future strategies for initiating measures to check the potential of $\mathrm{NO}_{3}{ }^{-}-\mathrm{N}$ leaching to groundwater. The delineation of high $\mathrm{NO}_{3}{ }^{-}-\mathrm{N}$ groundwater zones is also important for developing site-specific efficient fertilizer- $\mathrm{N}$ management strategies and prioritizing research and extension activities for disseminating robust fertilizer- $\mathrm{N}$ management strategies for such areas. Nonetheless, assessment and prediction of $\mathrm{NO}_{3}{ }^{-} \mathrm{N}$ concentration in groundwater has always been challenging in the context of controlling the $\mathrm{NO}_{3}{ }^{-}-\mathrm{N}$ pollution of groundwater [8]. Several mathematical models are available to study the interactions involved in $\mathrm{N}$ movement within the soil profile and to study the effects of different land use and management practices on $\mathrm{N}$ movement. The most used models are Soil Water Atmosphere Plant (SWAP) [9]—Agricultural NItrogen MOdel (ANIMO) [10], APSIM [11], CERES [12], DAISY [13], GLEAMS [14], LEACHM [15], NLEAP [16], and WAVE [17] models. The linking of SWAP-ANIMO constitutes a complex model designed to quantify the relationships between fertilizer use and soil and irrigation management for a wide range of soil types and hydrological conditions. The ANIMO model provides field and regional assessments with respect to groundwater and surface water $\mathrm{N}$ pollution, originating from the soil due to agricultural land use. The organic matter and $\mathrm{N}$ cycle are described in more detail in ANIMO than other models [18]. It calculates onedimensional solute transport, but the discharge to surface water has been based on a pseudo-two-dimensional concept.

The SWAP-ANIMO model has been used extensively to study $\mathrm{N}$ transport for different crops and under different agricultural management practices at the plot-, field-, and regional levels [19-23]. Most $\mathrm{N}$ leaching models are field-scale models. The upscaling of these field-scale models to regional applications requires integrating with GIS. Very few studies are available on the linkage of process-based $\mathrm{NO}_{3}{ }^{-}-\mathrm{N}$ leaching model with GIS [14,16,24].

The objectives of this study were to: (1) assess and predict the spatial variability of $\mathrm{NO}_{3}{ }^{-}-\mathrm{N}$ concentration in groundwater at a regional scale under the rice-wheat cropping system in the Punjab (India) by linking SWAP-ANIMO model with GIS and (2) evaluate the model performance using field data on soil moisture and $\mathrm{NO}_{3}{ }^{-}-\mathrm{N}$ concentration profiles Most of the studies pertaining to groundwater quality due to fertilizer- $\mathrm{N}$ use are either based on groundwater sampling or $\mathrm{NO}_{3}{ }^{-}-\mathrm{N}$ leaching below the rooting zone. In this investigation, $\mathrm{NO}_{3}{ }^{-}-\mathrm{N}$ movement has been studied and simulated throughout the soil profile up to the aquifer.

\section{Materials and Methods}

\subsection{Study Area}

The study area was located between the latitudes of $30^{\circ} 92^{\prime} 69^{\prime \prime}$ and $31^{\circ} 00^{\prime} 5^{\prime \prime} \mathrm{N}$, and the longitudes of $76^{\circ} 14^{\prime} 50^{\prime \prime}$ and $76^{\circ} 26^{\prime} 42^{\prime \prime}$ E with a geographical area of $60 \mathrm{~km}^{2}$ (Figure 1). The study area falls in the Machhiwara block of the Ludhiana district in the state Punjab in north-western India. The administrative block consists of 30 villages along the banks of the 
Satluj river. There was a considerable variation between the mean maximum temperature ( $42^{\circ} \mathrm{C}$ in June) and the mean minimum temperature $\left(4.7^{\circ} \mathrm{C}\right.$ in January). The Satluj river flows east to west, and its water is extensively used for irrigation. The area is considered especially vulnerable to $\mathrm{NO}_{3}{ }^{-}-\mathrm{N}$ leaching because of the coarse-textured soils, shallow water table, and excessive use of $\mathrm{N}$ fertilizers in the rice-wheat cropping system. The average annual rainfall in the study area varies from $300-1300 \mathrm{~mm}$, and a significant proportion (approximately 51\%) of this water flows during the monsoon season from July to September. Eighty percent of the annual rainfall is received during the summer monsoon season, and the rest is received during the winter season. The river erodes a tremendous amount of sediment from the Himalayas and deposits it in the plains of Punjab during floods. The altitude varies from 237 to $244 \mathrm{~m}$ above the mean sea level. The groundwater table depth in the area study varies from 2.05 to $4.30 \mathrm{~m}$ below the land surface. These floodplain soils alongside the Satluj river are classified as Typic Ustipsamments (USDA classification) and are slightly to moderately alkaline and excessively drained. The $\mathrm{pH}$ varies from 7.4 to 8.5 , while the electrical conductivity (EC) varies from 0.13 to $0.53 \mathrm{dSm}^{-1}$ with a mean value of $0.28 \mathrm{dSm}^{-1}$ (Tables 1 and 2). Most soils are calcareous, with calcium carbonate concentration as high as $6.35 \%$. The SOC content varies from 0.06 to $1.03 \%$, with a mean value of $0.54 \%$. The cation exchange capacity varies significantly, and soils are high in $\mathrm{K}$ content [25].

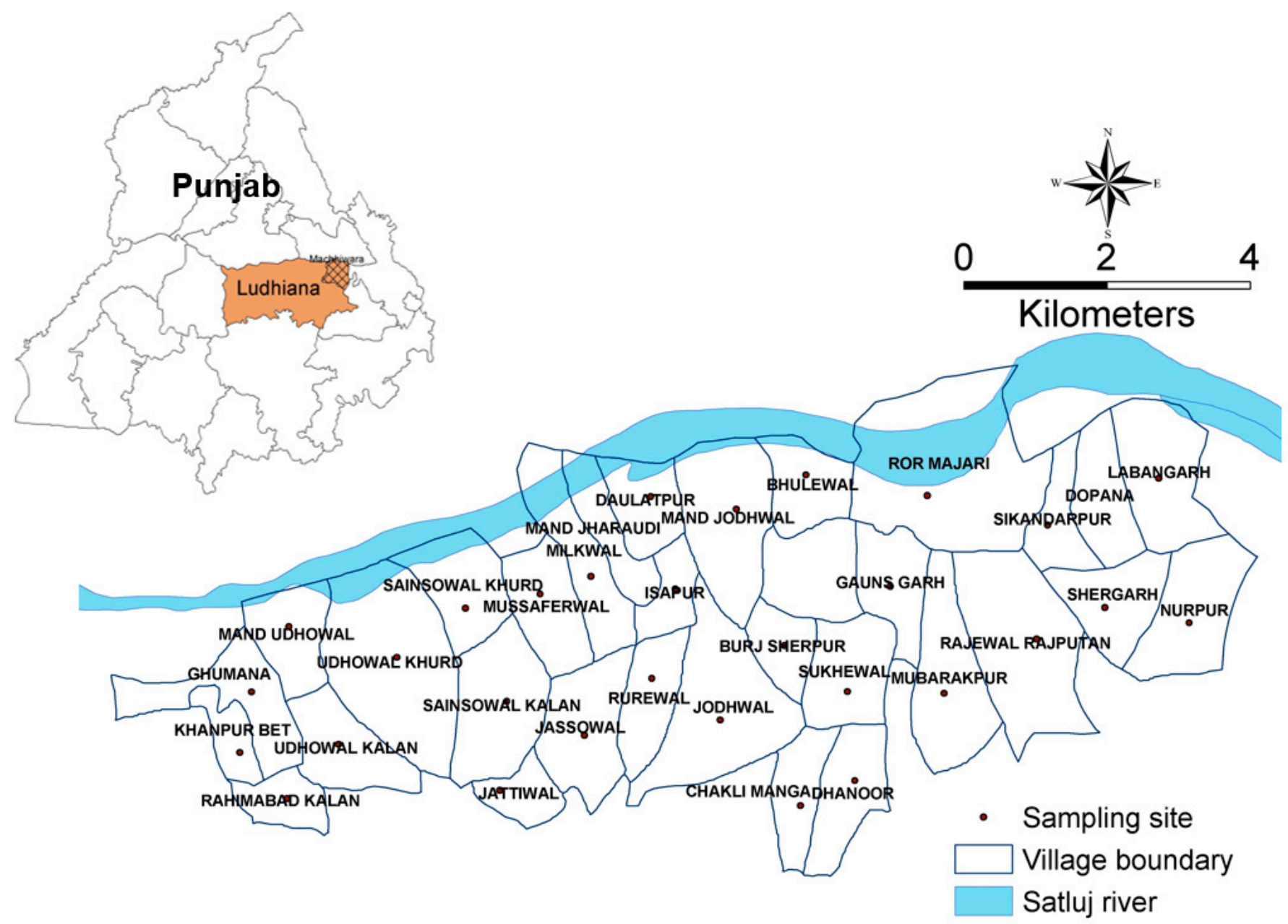

Figure 1. Location map of Machhiwara area with sampling sites. 
Table 1. Values of hydraulic parameters used for the SWAP-ANIMO simulation.

\begin{tabular}{lccc}
\hline \multicolumn{1}{c}{ Characteristics } & Symbol & $\begin{array}{c}\text { Soil Horizon I } \\
\mathbf{( 0 - 1 2 0 ~} \mathbf{~ m})\end{array}$ & $\begin{array}{c}\text { Soil Horizon II } \\
\mathbf{( 1 2 0 - 4 5 0 ~} \mathbf{~ c m})\end{array}$ \\
\cline { 3 - 4 } & & 0.049 & 0.081 \\
Residual moisture content $\left(\mathrm{cm}^{3} \mathrm{~cm}^{-3}\right)$ & $\theta_{\mathrm{r}}$ & 0.330 & 0.310 \\
Saturated moisture content $\left(\mathrm{cm}^{3} \mathrm{~cm}^{-3}\right)$ & $\theta_{\mathrm{s}}$ & 29.5 & 98.9 \\
Saturated hydraulic conductivity $\left(\mathrm{cm} \mathrm{d}^{-1}\right)$ & $\alpha$ & 0.062 & 0.079 \\
Alpha, main drying curve $\left(\mathrm{cm}^{-1}\right)$ & $\lambda$ & -3.100 & -0.610 \\
Exponent in hydraulic conductivity function & $\mathrm{n}$ & 1.170 & 3.000 \\
Soil shape function $(\mathrm{n})$ & $\alpha$ & 0.036 & 0.036 \\
Alpha, main wetting curve $\left(\mathrm{cm}^{-1}\right)$ & & & \\
\hline
\end{tabular}

Table 2. Values of nitrogen transport and transformation parameters used for the SWAP- ANIMO simulation.

\begin{tabular}{|c|c|c|c|c|}
\hline Parameter & Units & Range & Wheat & Rice \\
\hline $\begin{array}{l}\text { Mass fraction of fresh organic material not passing a } \\
\text { dissolved stage but transformed directly into humus }\end{array}$ & $\mathrm{kg} \mathrm{kg}^{-1}$ & $0-1$ & 0.99 & 0.125 \\
\hline Assimilation factor & & $0-1$ & 0.99 & 0.17 \\
\hline $\begin{array}{l}\text { Reduction factor for organic dissolved matter under oxygen } \\
\text { limited conditions }\end{array}$ & & $0-1$ & 0.365 & 0.30 \\
\hline Decomposition for organic dissolved matter & $\mathrm{a}^{-1}$ & $0.01-100$ & 10 & 10 \\
\hline Decomposition for humus biomass & $a^{-1}$ & $0.01-100$ & 0.02 & 0.02 \\
\hline Nitrification rate & $a^{-1}$ & $10-500$ & 20 & 30 \\
\hline Denitrification rate & $\mathrm{d}^{-1}$ & $0.01-1$ & 0.01 & 0.025 \\
\hline Nitrogen content of organic classes & $\mathrm{kg} \mathrm{kg}^{-1}$ & $0-1$ & 0.007 & 0.022 \\
\hline Nitrogen content of humus biomass & $\mathrm{kg} \mathrm{kg}^{-1}$ & $0-1$ & 0.048 & 0.025 \\
\hline Nitrogen content of exudates & $\mathrm{kg} \mathrm{kg}^{-1}$ & $0-1$ & 0.025 & 0.025 \\
\hline Expected cumulative $\mathrm{N}$-uptake by crop in first period & $\mathrm{kg} \mathrm{ha}^{-1}$ & $10-800$ & 128 & 113 \\
\hline Expected cumulative $\mathrm{N}$-uptake in second period & $\mathrm{kg} \mathrm{ha}^{-1}$ & $10-800$ & 78 & 84 \\
\hline Cumulative transpiration in first period & $\mathrm{m}$ & $0-1$ & 0.167 & 0.167 \\
\hline Cumulative transpiration in Second period & $\mathrm{m}$ & $0-1$ & 0.123 & 0.123 \\
\hline Day when maximum $\mathrm{N}$-uptake rate alters & & $1-366$ & 100 & 255 \\
\hline Maximum selectivity factor for $\mathrm{N}$-uptake & & $0.5-1$ & 0.75 & 0 \\
\hline Relative duration of sunshine & & $0.1-0.5$ & 0.37 & 0.46 \\
\hline Frequency of yearly temperature wave & $\operatorname{rad~d}^{-1}$ & $0.001-0.03$ & 0.0173 & 0.0173 \\
\hline Thermal diffusivity & $\mathrm{m}^{2} \mathrm{~d}^{-1}$ & $0.01-0.1$ & 0.052 & 0.052 \\
\hline Amplitude of yearly sinus wave & ${ }^{\circ} \mathrm{C}$ & 0-20 & 10 & 10 \\
\hline Average yearly temperature at soil surface & ${ }^{\circ} \mathrm{C}$ & $0-20$ & 11 & 11 \\
\hline Dry bulk density & $\mathrm{kg} \mathrm{m}^{-3}$ & $500-2650$ & 1500,1570 & 1500,1570 \\
\hline Diffusion constants & & $0.3-5$ & $3.0,4.2$ & $3.0,4.2$ \\
\hline $\mathrm{C} / \mathrm{N}$ ratio & & $5-60$ & 35,30 & 10,30 \\
\hline $\mathrm{pH}$ water & & 2-12 & $7.5,7.0$ & $7.5,7.0$ \\
\hline Sorption coefficient of $\mathrm{NH}_{4}{ }^{+}-\mathrm{N}$ & $\mathrm{m}^{3} \mathrm{~kg}^{-1}$ & $0.00001-0.001$ & 0.000043 & 0.000043 \\
\hline Aeric matter of roots (dry matter) & $\mathrm{kg} \mathrm{m}^{-2}$ & 0-20 & 0.025 & 2.5 \\
\hline Aeric matter of shoots (dry matter) & $\mathrm{kg} \mathrm{m}^{-2}$ & $0-20$ & 0 & 2.5 \\
\hline Aeric matter of nitrogen present in crop & $\mathrm{kg} \mathrm{m}^{-2}$ & $0-800$ & 0.002 & 0 \\
\hline Organic matter content in fertilizer & $\mathrm{kg} \mathrm{kg}^{-1}$ & $0-1$ & 0 & 0 \\
\hline Mineral $\mathrm{NH}_{4}{ }^{+}-\mathrm{N}$ content in fertilizer & $\mathrm{kg} \mathrm{kg}^{-1}$ & $0-1$ & 0.46 & 0.46 \\
\hline Mineral $\mathrm{NO}_{3}{ }^{-}-\mathrm{N}$ content in fertilizer & $\mathrm{kg} \mathrm{kg}^{-1}$ & $0-1$ & 0 & 0 \\
\hline
\end{tabular}

\subsection{Experimental Details}

Thirty sampling sites were earmarked by randomly selecting one site in each of the thirty villages to assess $\mathrm{NO}_{3}{ }^{-}-\mathrm{N}$ contamination of the groundwater. Soil and water samples were collected from boreholes between 22 April and 15 May 2004. The water table depths ranged between 4.5 and $6.0 \mathrm{~m}$ below the soil surface at sites. Soil samples were collected at 0-15, 15-30, and 30-60 cm depths and $30 \mathrm{~cm}$ depth increment afterward up to the groundwater table. A sample of groundwater was also taken from each borehole. 
The information on local soil management and crop production practices viz. fertilizer application and irrigation scheduling, were collected for each experimental site, and it was used as input in the SWAP-ANIMO models.

Soil samples were analyzed in the laboratory for moisture content, soil texture (international pipette method), $\mathrm{pH}$ (1:2 soil water ratio), bulk density (core analysis), soil organic $\mathrm{C}$, and $\mathrm{NO}_{3}{ }^{-}-\mathrm{N}$ and ammoniacal- $\mathrm{N}\left(\mathrm{NH}_{4}{ }^{+}-\mathrm{N}\right)$ concentrations. The meteorological data-daily precipitation, minimum and maximum daily air temperature, mean daily hours of sunshine, and wind speed-were collected from the Department of Agronomy and Agro-meteorology at the Punjab Agricultural University Ludhiana, Punjab (India).

\subsection{Modelling Approach}

The water hydrology model, SWAP version $2.07 \mathrm{~d}$ and ANIMO model version 3.7 were used in the present study. The SWAP model numerically solves the Richard's general water flow equation integrally for the unsaturated-saturated zone, including possible transient and perched groundwater levels subjected to given specified initial and final boundary conditions. The initial pressure heads were supplied as initial boundary conditions, while the bottom boundary was provided either according to Dirichlet, Neumann, or Cauchy conditions. The ANIMO model distinguishes five leaching substances: three soluble $\mathrm{N}$ substances $\left(\mathrm{NO}_{3}{ }^{-}-\mathrm{N}, \mathrm{NH}_{4}{ }^{+}-\mathrm{N}\right.$, and dissolved organic-N) and the two soluble phosphorus substances (mineral-P and dissolved organic-P.) In the present study, however, only the quantification of $\mathrm{NO}_{3}{ }^{-}-\mathrm{N}$ leaching was considered. The $\mathrm{NO}_{3}{ }^{-}-\mathrm{N}$ in the model is principally based on mass conservation and transport equation. The model utilizes a semi-analytical solution of the conservation and transport differential equation. The model requires the initial values of soil moisture contents for each distinguished class of fresh material and pools of humus/biomass, exudates, and dissolved organic matter. The initial estimates of the fresh materials have a significant influence on mineralization. The bottom conditions were entered into the model and specified for all soluble substances for the boundaries at the top, lateral, and bottom of the simulated soil system. The boundary condition at the top was given as a concentration of the incoming precipitation water flux. The boundary condition at lateral sides of the model system was given as concentration in the incoming (infiltrating) surface-water flux. The boundary condition at the bottom was given as a concentration in the incoming seepage water flux.

\subsection{Model一GIS Linkage}

The SWAP-ANIMO model was used to simulate $\mathrm{NO}_{3}{ }^{-}-\mathrm{N}$ leaching for each sampling site before integrating with GIS Arc-GIS software to analyze the spatial distribution of $\mathrm{NO}_{3}{ }^{-}-\mathrm{N}$ concentration in groundwater using specified values of various model parameters (Tables 1 and 2). The SWAP-ANIMO model has already been calibrated and validated for the rice-wheat cropping system for the Indian Punjab conditions [26]. The observed $\mathrm{NO}_{3}{ }^{-}-$ $\mathrm{N}$ concentration values in the groundwater at all thirty locations were used as inputs for the integrated SWAP-ANIMO-GIS model (Figures 2 and 3). The predicted spatial variability maps of $\mathrm{NO}_{3}{ }^{-}-\mathrm{N}$ concentration in leachate were prepared for 2004-2005 growing seasons. The $\mathrm{NO}_{3}-\mathrm{N}$ concentration was classified into five categories: very low $\left(0-2 \mathrm{mg} \mathrm{kg}^{-1}\right)$, low (2-4 mg kg $\left.{ }^{-1}\right)$, medium (4-7 $\left.\mathrm{mg} \mathrm{kg}^{-1}\right)$, high (7-10 $\left.\mathrm{mg} \mathrm{kg}^{-1}\right)$, and very high $\left(>10 \mathrm{mg} \mathrm{kg}^{-1}\right)$. 

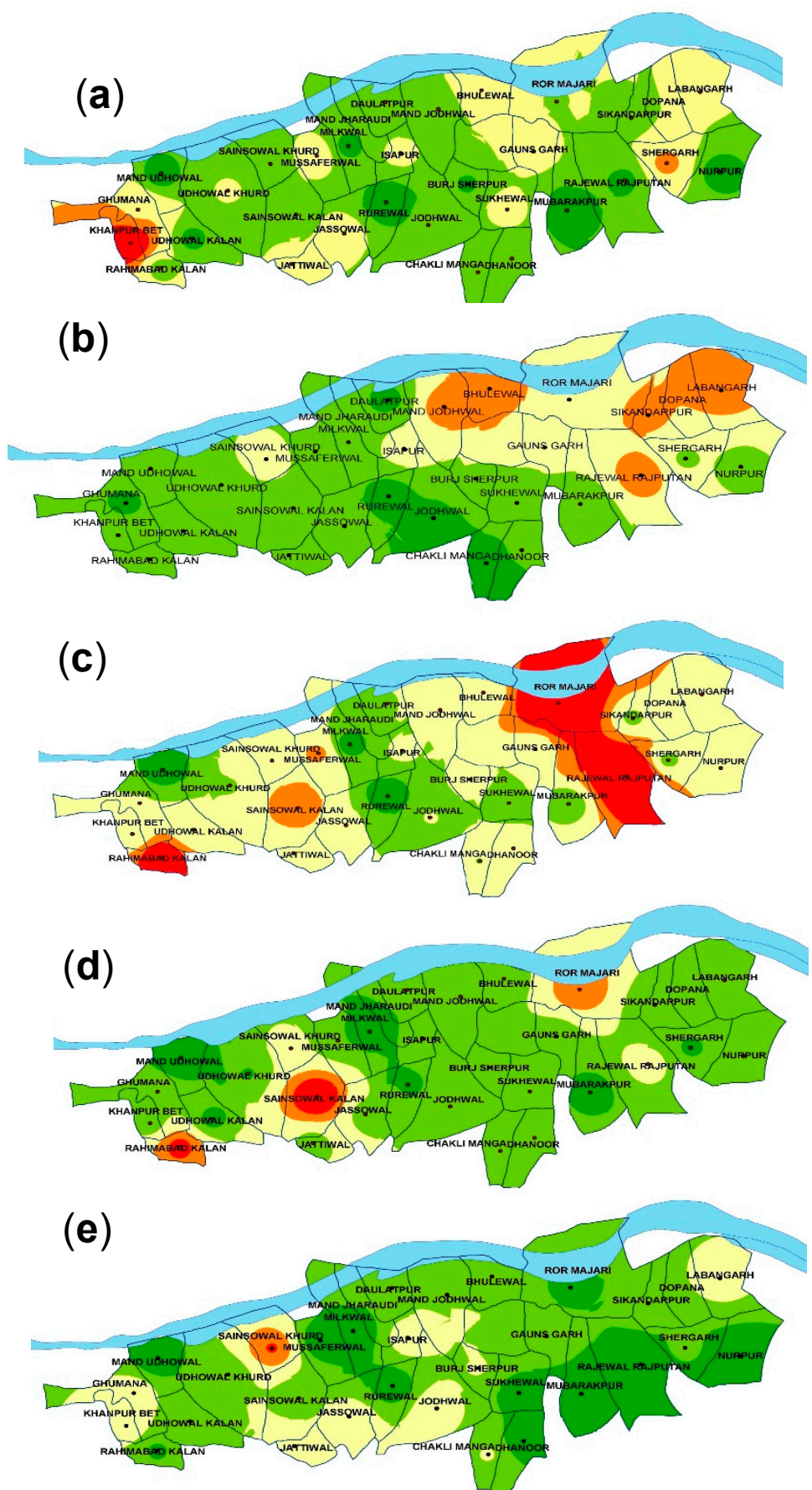

Nitrate concentration $(\mathrm{mg} / \mathrm{L})$

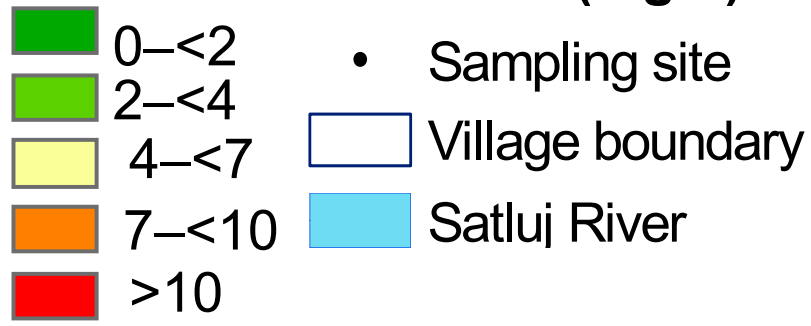

Figure 2. Spatial variability maps of nitrate concentration in groundwater $(\mathrm{mg} / \mathrm{L})$ during 2004 rice season (a) Jun-20, (b) Jun-30, (c) Jul-30, (d) Aug-31, and (e) Sep-30. 

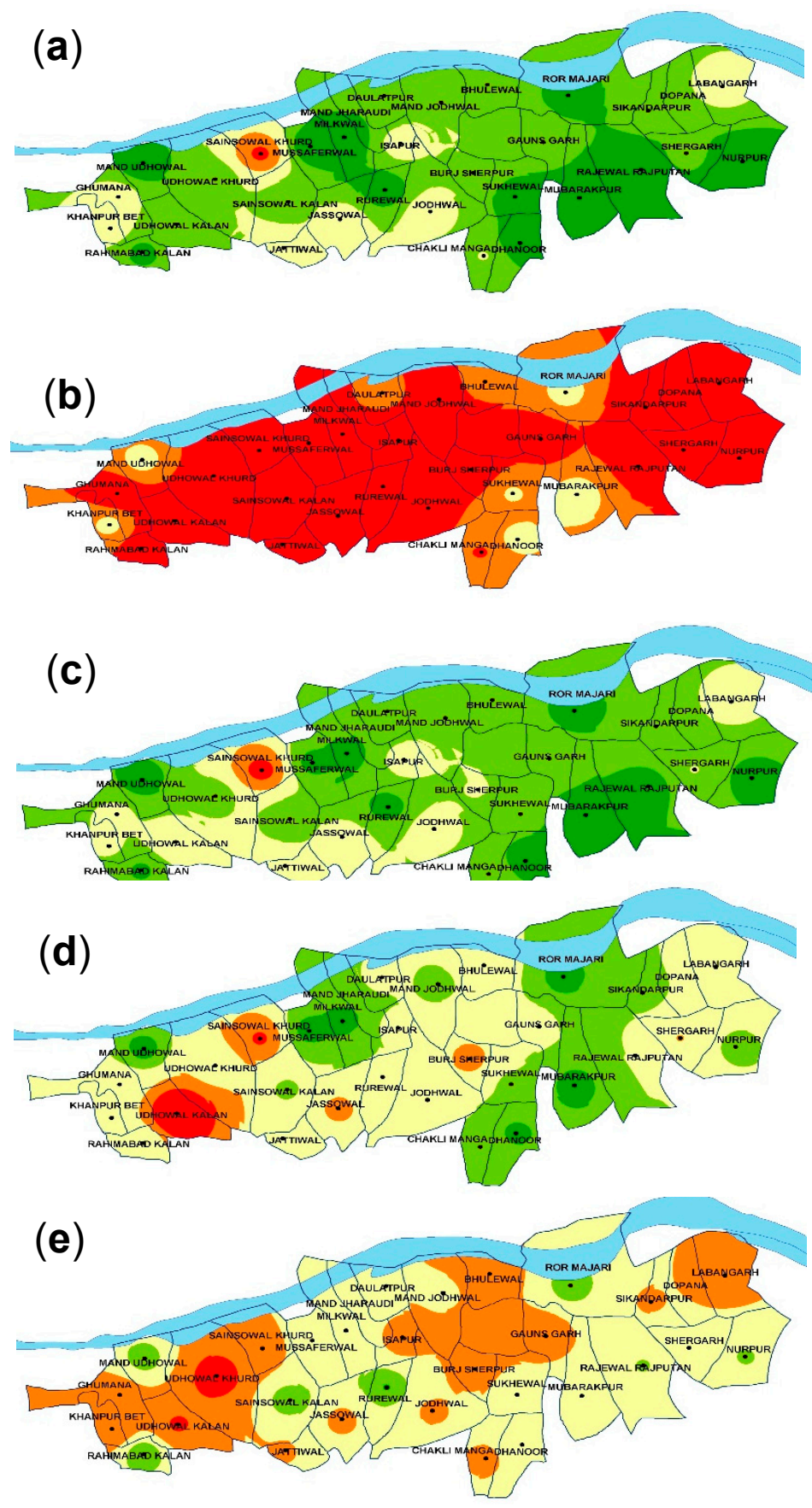

\section{Nitrate concentration (mg/L)}

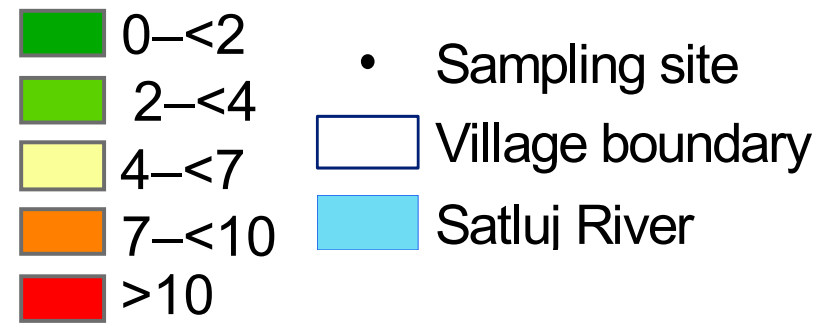

Figure 3. Spatial variability maps of nitrate concentration in groundwater (mg/L) during 2004-2005 wheat season (a) Nov-10, (b) Dec-31, (c) Jan-31, (d) Feb-28, and (e) Apr-10. 
The SWAP-ANIMO model outputs for each sample site were transformed into database files (dbf files.). The dbf files were fed into GIS by assigning unique IDs for each sample site. The field-specific model output was spatially joined using the kriging interpolation technique of GIS. The kriging method of interpolation was used to obtain the spatial distribution of $\mathrm{NO}_{3}{ }^{-}-\mathrm{N}$ concentration in groundwater on a regional scale. The kriging interpolation method weighs the surrounding measured values to derive a prediction for an unmeasured location. Weights are based on the distance between the measured points, the prediction location, and the overall spatial arrangement [27].

\subsection{Statistical Analysis}

To evaluate the performance of the SWAP-ANIMO models statistical criteria was performed in terms of the magnitude of error between measured (observed) and simulated changes in $\mathrm{NO}_{3}{ }^{-}-\mathrm{N}$ and $\mathrm{NH}_{4}{ }^{+}-\mathrm{N}$ concentration through the coefficient of correlation (r), mean absolute error (MAE), and the root mean square error (RMSE). The lowest possible value of MAE and RMSE is zero, indicating that there is no difference between the simulated and measured data. The Wilcoxon statistical test was used to determine the statistically significant difference between measured and predicted values of soil moisture and $\mathrm{NO}_{3}{ }^{-}-\mathrm{N}$ concentration across the soil profile during the validation at five sampling sites.

\section{Results}

\subsection{Spatial and Temporal Distribution of $\mathrm{NO}_{3}{ }^{-}-\mathrm{N}$ Concentration in Groundwater}

During the rice-growing season, the area under the medium and high $\mathrm{NO}_{3}{ }^{-}-\mathrm{N}$ concentrations categories increased until July and decreased afterward (Figure 2). However, the area under the low $\mathrm{NO}_{3}{ }^{-}-\mathrm{N}$ category increased because unused fertilizer- $\mathrm{N}$ applied during the preceding wheat crop leaches to groundwater with irrigation and rainwater. The long-term precipitation data in the study revealed that precipitation during the monsoon season extending to June until the end of July is approximately $70 \%$ of the total precipitation $(700-800 \mathrm{~mm})$. The most significant $\mathrm{NO}_{3}{ }^{-}-\mathrm{N}$ leaching events occurred after high precipitation events, which resulted in a decrease of $\mathrm{NO}_{3}{ }^{-}-\mathrm{N}$ concentrations. In the present study, only a few rainfall events were recorded after July, and that may be the reason for the diminished fertilizer- $\mathrm{N}$ leaching into the leachate. There was no significant increase in the $\mathrm{NO}_{3}{ }^{-}-\mathrm{N}$ concentration of leachate from August to October (when rice is harvested) due to the application of the small amount of irrigation water during this period. There was no change in $\mathrm{NO}_{3}{ }^{-}-\mathrm{N}$ concentration of leachate in the study area from the rice harvest to the sowing of wheat since the land was fallow during this time, and no fertilizer- $\mathrm{N}$ was applied.

The $\mathrm{NO}_{3}{ }^{-}-\mathrm{N}$ concentrations in the leachate of the study area during the wheat crop season showed a significant increase in the $\mathrm{NO}_{3}{ }^{-}-\mathrm{N}$ concentration of the leachate after sowing the wheat crop in December (Figure 3). In most areas, the $\mathrm{NO}_{3}{ }^{-}-\mathrm{N}$ concentration of leachate was above the critical limit of $10 \mathrm{mg} \mathrm{kg}^{-1}$. The $\mathrm{NO}_{3}{ }^{-}-\mathrm{N}$ concentration in groundwater decreased in January, but a significant increase in $\mathrm{NO}_{3}{ }^{-}-\mathrm{N}$ concentration was found in the medium and high $\mathrm{NO}_{3}{ }^{-}-\mathrm{N}$ categories in February and April predictions, though it was still below the critical limit. The kriging means of $\mathrm{NO}_{3}{ }^{-}-\mathrm{N}$ concentrations in leachate during the 2004-2005 rice-wheat growing season were above the critical limits only at the end of December 2004 and decreased afterward (Figure 4).

\subsection{Validation of Simulations}

The simulation of soil moisture profiles and $\mathrm{NO}_{3}{ }^{-}-\mathrm{N}$ leaching to groundwater of a GIS-linked SWAP-ANIMO model were compared with the measured soil moisture and $\mathrm{NO}_{3}{ }^{-}-\mathrm{N}$ concentration distribution for five different sampling sites viz. Ghumana, Sainsowal Khurd, Jattiwal, Jodhwal, and Bhulewal (Figures 5 and 6). The sites were selected to verify the model results for three soil types (sand, loamy sand, and sandyloam). The model statistics obtained by comparing the measured moisture and $\mathrm{NO}_{3}{ }^{-}-\mathrm{N}$ content distributions and predicted by the SWAP-ANIMO model are given in Table 3 . The 
comparisons were explicitly made for 21 September, a few weeks before the harvesting time for the rice crop, so neither fertilizer nor irrigation water was applied during that period.

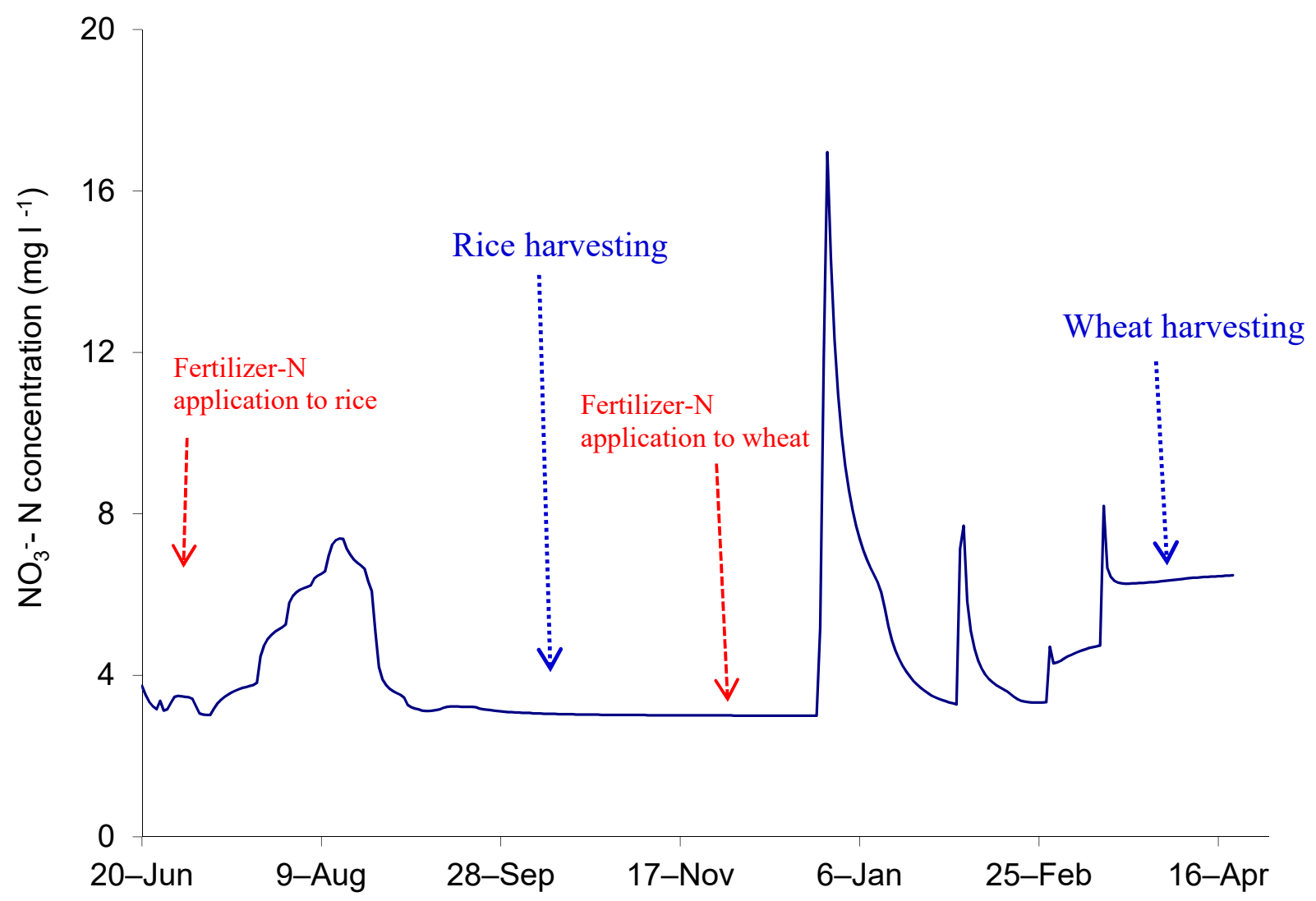

Figure 4. Predicted mean groundwater nitrate concentration of the study area for 2004-2005 rice-wheat cropping cycle.

Table 3. Statistical comparison of measured and predicted values of soil moisture $\left(\mathrm{cm}^{3} \mathrm{~cm}^{-3}\right)$ and $\mathrm{NO}_{3}{ }^{-} \mathrm{N}$ concentration $\left(\mathrm{mg} \mathrm{kg}^{-1}\right)$ across the soil profile during the validation of five sampling sites (Acronyms: MAE = mean absolute error, $r=$ coefficient of correlation, $p=$ Wilcoxon $p$-value of significant differences, and RMSE = root mean square error.

\begin{tabular}{ccccc}
\hline Sampling Site & MAE & r & $p$ & RMSE \\
\hline Ghumana & 0.031 & 0.86 & 0.38 & 0.034 \\
Sainsowal Khurd & 0.025 & 0.79 & 0.64 & 0.029 \\
Jattiwal & 0.028 & 0.88 & 0.88 & 0.033 \\
Jodhwal & 0.028 & 0.74 & 0.12 & 0.035 \\
Bhulewal & 0.028 & 0.79 & 0.71 & 0.033 \\
Ghumana & 1.100 & 0.87 & 0.43 & 1.336 \\
Sainsowal Khurd & 1.375 & 0.87 & 0.75 & 1.521 \\
Jattiwal & 0.840 & 0.78 & 0.27 & 1.099 \\
Jodhwal & 0.720 & 0.84 & 0.71 & 0.932 \\
Bhulewal & 0.488 & 0.83 & 0.60 & 0.619 \\
\hline
\end{tabular}




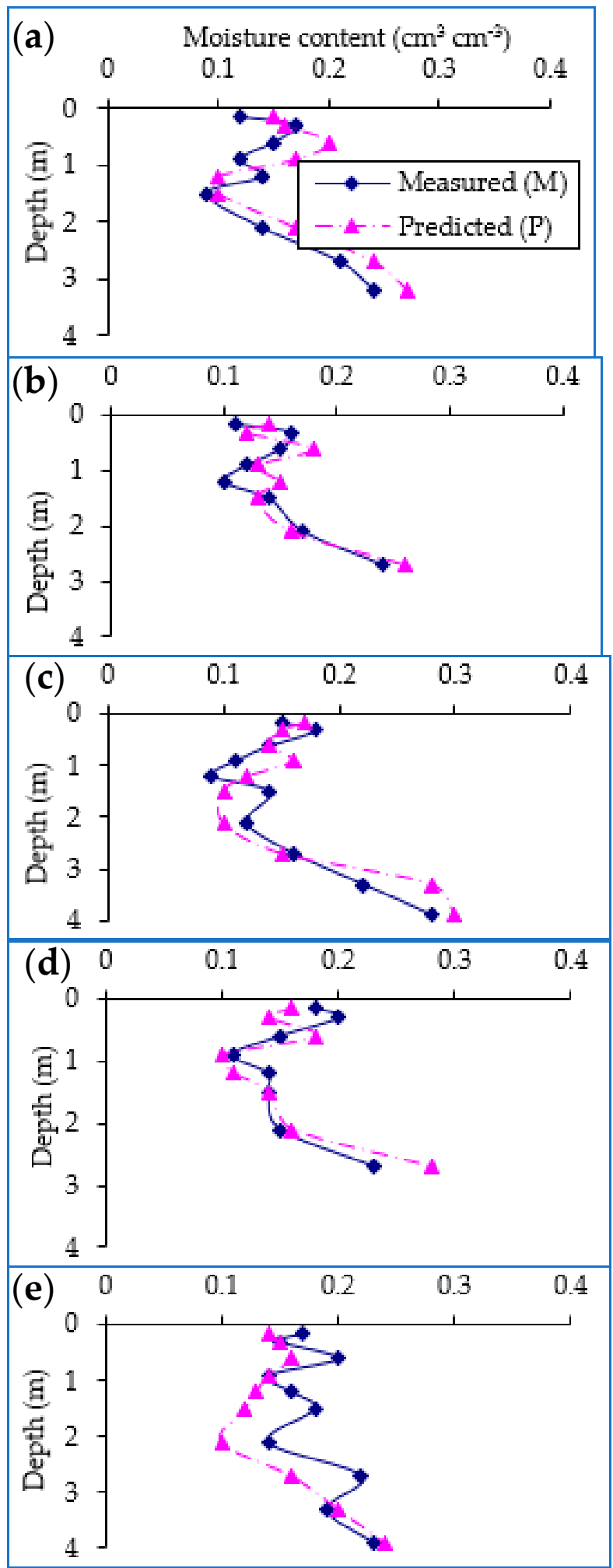

Figure 5. Comparison of measured and predicted soil moisture $\left(\mathrm{cm}^{3} \mathrm{~cm}^{-3}\right)$ across the soil profile on 21/09/2004 of sampling site (a) Ghumana village (b) Sainsowal Khurd (c) Jattiwal (d) Jodhwal (e) Bhulewal. 

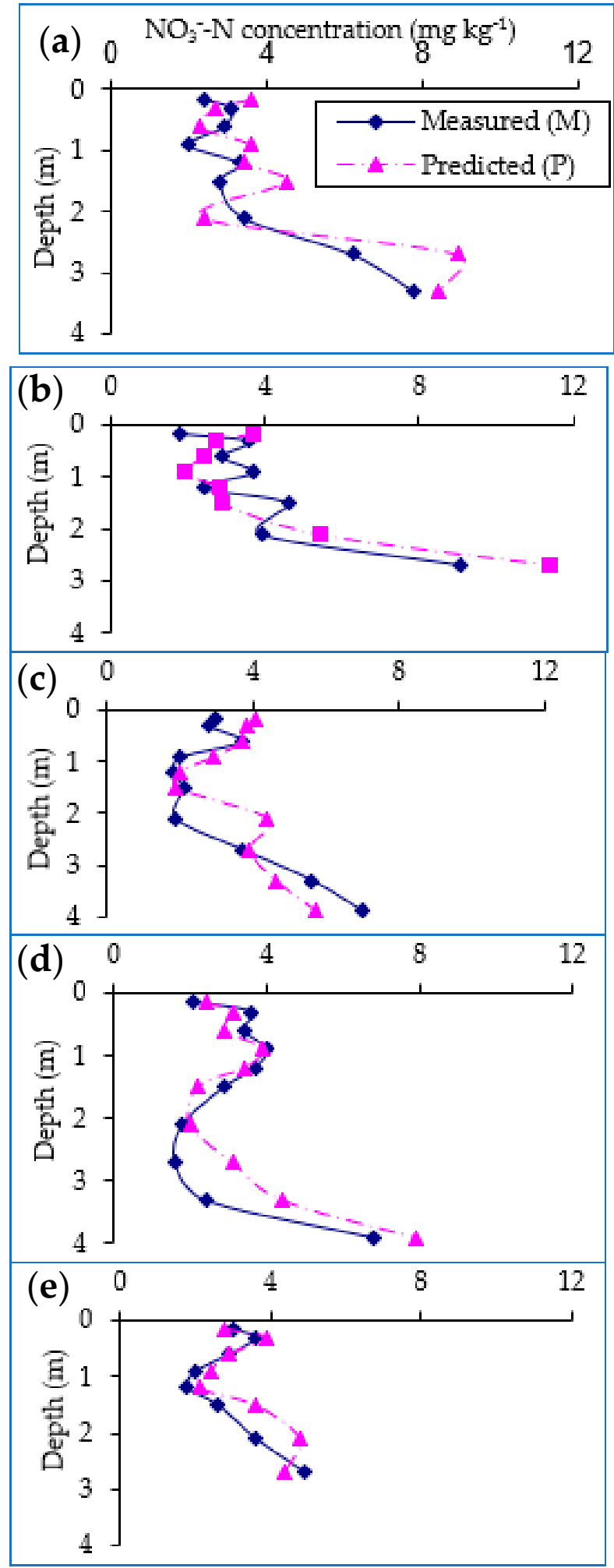

Figure 6. Comparison of measured and predicted $\mathrm{NO}_{3}{ }^{-}-\mathrm{N}$ concentration $\left(\mathrm{mg} \mathrm{kg}^{-1}\right)$ across the soil profile on 21/09/2004 of sampling site (a) Ghumana village (b) Sainsowal Khurd (c) Jattiwal (d) Jodhwal (e) Bhulewal.

The measurements made at five sampling sites indicate that the water regime within the profile was similar throughout the region. The most remarkable change in the soil water content was within the root zone; water movement slowed down in the deeper part 
of the profile. Panhwar et al. [28] reported similar results from field measurements in the coarse-textured soils.

The soil moisture content at all the depths of the selected sites varied between 9 to $28 \%$ (Figure 5). The results show that the upper part $(0-10 \mathrm{~cm})$ of the soil profile representing the root zone was dry. In contrast, deeper soil layers remained relatively moist. The moisture content was $10 \%$ at about $1.0 \mathrm{~m}$ depth and continuously increased with depth. Water content throughout the profile reached near field capacity with a moisture content of around $0.2 \mathrm{~cm}^{3} \mathrm{~cm}^{-3}$.

A good agreement between measured and predicted soil moisture content distributions throughout the soil profile and groundwater for all the sampling sites was observed (Figure 5). These conclusions are also supported by the descriptive statistics (Table 3). The Wilcoxon statistical test results showed that the predicted soil moisture contents were identical to the measured values at a significant level of $\alpha=0.05$ for all sites and a low value of $\mathrm{r}(0.74)$. However, the RMSE values provide a more detailed picture of the model performance. The RMSE from the measured and predicted soil water content was estimated at about $20 \%$ of all the sites, while $r$ values were between 0.74 and 0.88 . The MAE values were also in the acceptable range for all the sites.

The $\mathrm{NO}_{3}{ }^{-}-\mathrm{N}$ concentrations in each soil layer for all sampling sites were used to evaluate the performance of the model with respect to $\mathrm{NO}_{3}{ }^{-}-\mathrm{N}$ leaching. Concentrations of $\mathrm{NO}_{3}{ }^{-}-\mathrm{N}$ at various depths within the entire profile were predicted reasonably well by the SWAP-ANIMO model and compared favorably with the measured values at the five sites (Figure 6). The variation between the measured and predicted $\mathrm{NO}_{3}{ }^{-}-\mathrm{N}$ values was below $1 \mathrm{mg} \mathrm{kg}^{-1}$ for most of the depths except for the lower two depths, assumed to be in the capillary zone where significant differences were observed. A depth-wise analysis of soil $\mathrm{NO}_{3}{ }^{-}-\mathrm{N}$ content distribution indicated no regular pattern up to $2.0 \mathrm{~m}$, but it increased with depth. A similar trend was observed in the soil water content distributions for the five sites. Continuous $\mathrm{NO}_{3}{ }^{-}-\mathrm{N}$ leaching below the root zone was also observed for all sites. Soil moisture profiles reveal that the water moved below $1.0 \mathrm{~m}$. The RMSE values from the measured and predicted $\mathrm{NO}_{3}{ }^{-}-\mathrm{N}$ concentrations were slightly greater than those from the soil water contents (Table 3). The r values were more than 0.80 in the sampling sites under study, while the MAE values were between 0.5 and 1.4. The Wilcoxon statistical test results showed that the $\mathrm{NO}_{3}{ }^{-}-\mathrm{N}$ content across the soil profiles at each site were identical between predicted and measured values at a significant level of $\alpha=0.05$. The RMSE values were also acceptable, at $20 \%$ and $29 \%$ for the Bhulewal and Jodhwal sites, respectively. For the other three sites, the values were below $40 \mathrm{mg} \mathrm{kg}^{-1}$.

\subsection{Predictions of $\mathrm{NO}_{3}{ }^{-}-\mathrm{N}$ Concentrations}

The simulations were extended beyond the 2004 growing season to predict the impact of $\mathrm{N}$ leaching of local agricultural management practices in the study area using the calibrated and validated GIS-integrated SWAP-ANIMO model. The fertilizer-N rates were modeled between 240 and $275 \mathrm{~kg} \mathrm{ha}^{-1}$ for wheat and rice. The first dose of fertilizer-N was applied to wheat at the time of sowing (half of the total application), and the remaining half was applied 28 days after sowing. In rice, fertilizer- $\mathrm{N}$ in three equal split doses: at transplanting and at 21 and 42 days after transplanting. The amount of irrigation water used for the simulation varied from 375 to $525 \mathrm{~mm}$ for wheat and 1500 to $1900 \mathrm{~mm}$ for rice. These application rates covered the typical range used by farmers in the region. The simulations were designed to estimate the possible long-term $\mathrm{N}$ fluxes to groundwater from the soil under existing irrigation and fertilizer practice. The validated model was used to simulate and predict the $\mathrm{NO}_{3}{ }^{-}-\mathrm{N}$ concentration in groundwater for the study area up to 2015 (Figure 7) because the soil-water-plant system reaches a steady-state with respect to N distribution for more extended periods. For each year, a periodic repetition of the existing irrigation and fertilizer application was assumed. The results obtained the end of the growing season were considered for the simulation initial conditions for the simulations 
for the year. The average meteorological records for the previous 15 years at the nearby station (about $15 \mathrm{~km}$ away) were used as the periodic repetition for the simulations.

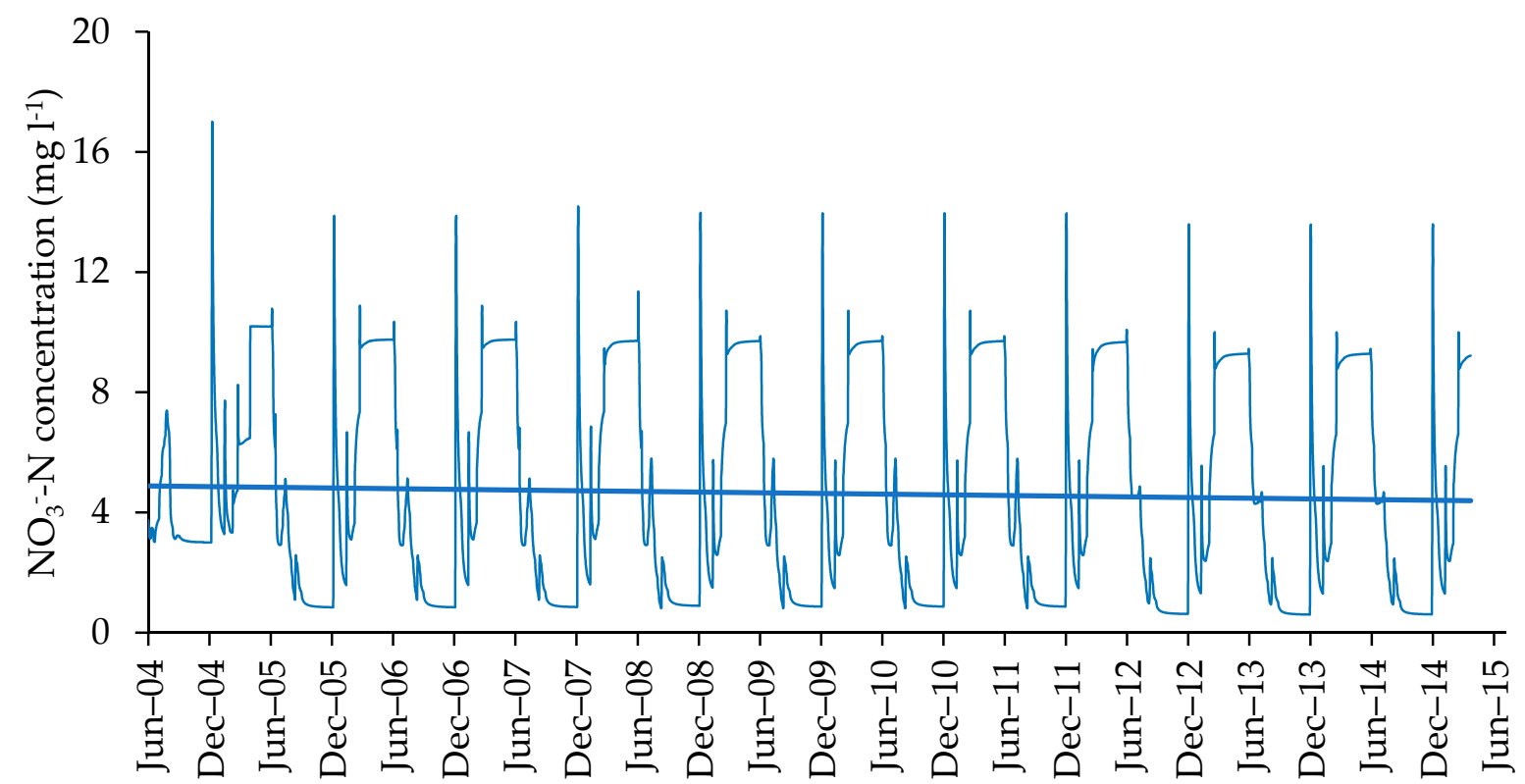

Figure 7. Temporal predictions of groundwater $\mathrm{NO}_{3}{ }^{-}-\mathrm{N}$ concentration of the study area. The solid blue line represent the linear trendline over the period.

\section{Discussion}

Nitrogen is the most consumed input for agriculture production, and its overuse can have a negative, long-lasting impact on water quality. This study was designed to link a previously calibrated and validated SWAP-ANIMO model [26] with GIS to make spatial and temporal predictions of $\mathrm{NO}_{3}{ }^{-}-\mathrm{N}$ concentration in the groundwater under rice-wheat cropping system for Indian Punjab conditions. The peaks in $\mathrm{NO}_{3}{ }^{-}-\mathrm{N}$ concentration in groundwater during the rice growing season were observed after high precipitation events. The $\mathrm{NO}_{3}{ }^{-}-\mathrm{N}$ leaching to groundwater modeled with a topsoil N-budget model in orchard farming had a similar trend after high precipitation events [29]. Similar results were found in Valencia, Spain, in an 8-year study on $\mathrm{NO}_{3}{ }^{-}-\mathrm{N}$ leaching for different $\mathrm{N}$ fertilization rates using the GIS-GLEAMS system [14]. The increase in $\mathrm{NO}_{3}{ }^{-}-\mathrm{N}$ concentration was less along the banks of the river Satluj also because of dilution from the river water (Figure 2). Xue et al. [30] observed a similar decrease in $\mathrm{NO}_{3}{ }^{-}-\mathrm{N}$ concentration levels due to the dilution of $\mathrm{NO}_{3}{ }^{-}-\mathrm{N}$ in the mainstream river.

A sudden increase in the $\mathrm{NO}_{3}{ }^{-}-\mathrm{N}$ concentration in leachate was observed in December (wheat growing season). It may be due to leaching of the fertilizer-N applied to the preceding rice crop to the lower depths of the soil profile at the end of November and December, when the first irrigation was applied to wheat. The first dose of fertilizer- $\mathrm{N}$ was applied to wheat in December (about one month after sowing). The leaching of applied fertilizer- $\mathrm{N}$ to wheat might also have contributed to the $\mathrm{NO}_{3}{ }^{-}-\mathrm{N}$ leaching observed at the end of December. Many studies have shown that $\mathrm{NO}_{3}{ }^{-}-\mathrm{N}$ leaching occurs more often in winter than summer [31,32]. Once the soil becomes wet, large reserves of $\mathrm{N}$ stimulate microbial activity, enhancing $\mathrm{NO}_{3}{ }^{-}-\mathrm{N}$ leaching in the winter. The increased microbial activity tends to remove more available $\mathrm{N}$ than that preserved during the previous summer. Seasonal fluctuations in $\mathrm{NO}_{3}{ }^{-}-\mathrm{N}$ concentration in leachate could be due to dilution from seepage of the adjacent river, rain, and irrigation water.

The spatial and temporal predictions of $\mathrm{NO}_{3}{ }^{-}-\mathrm{N}$ concentration in groundwater showed less $\mathrm{NO}_{3}{ }^{-}-\mathrm{N}$ in leachate during the rice crop season than during the wheat crop season. The relatively high $\mathrm{NO}_{3}{ }^{-}-\mathrm{N}$ in leachate during the wheat crop season was because of the mass movement of $\mathrm{NO}_{3}{ }^{-}-\mathrm{N}$ in the soil profile that could have started during the 
preceding rice crop due to excess irrigation water and reaching the groundwater during the wheat crop season. These results elucidate that high $\mathrm{NO}_{3}{ }^{-}-\mathrm{N}$ concentration levels in the preceding winter lead to lower concentrations in the following summer. Heavy rainfall events occurring in the winter could flush out residual $\mathrm{NO}_{3}{ }^{-}-\mathrm{N}$, leaving little residual amount in the following summer. El-Sadek et al. [31] also found that a high $\mathrm{NO}_{3}{ }^{-}-\mathrm{N}$ concentration preceding winter affects lowering concentrations in the following summer. Lower values in the preceding summer increase the $\mathrm{NO}_{3}{ }^{-}-\mathrm{N}$ concentrations in the following winter.

The simulation of soil moisture profiles and $\mathrm{NO}_{3}{ }^{-}-\mathrm{N}$ leaching to groundwater of a GISlinked SWAP-ANIMO model was compared with the measured soil moisture and $\mathrm{NO}_{3}{ }^{-}-\mathrm{N}$ concentration distribution for five different sampling sites viz. Ghumana, Sainsowal Khurd, Jattiwal, Jodhwal, and Bhulewal (Figures 5 and 6).

The measurements made at these sites indicate that the water regime within the profile was similar throughout the region. The most remarkable change in soil water content was within the root zone. Panhwar et al. [28] reported similar results in field measurements on coarse-textured soils. As $\mathrm{NO}_{3}{ }^{-}-\mathrm{N}$ is highly soluble in water, the $\mathrm{NO}_{3}{ }^{-}-\mathrm{N}$ moved along with water continuously below the $1.5 \mathrm{~m}$ depth. Similar results were observed by Singh and Sondhi [33] using the LEACHM model. The difference between the measured and predicted $\mathrm{NO}_{3}{ }^{-}-\mathrm{N}$ content in the upper soil layers may be attributed to the complex phenomenon of the root zone and the change of sudden soil texture at $1.2 \mathrm{~m}$ from clayloam to loamy-sand. However, Singh and Sondhi [33] attributed these discrepancies to spatial variation in the field and complex biological and chemical processes active in the natural system. Comparing the simulation results with the experimental data reveals that the SWAP-ANIMO model can effectively predict the $\mathrm{NO}_{3}{ }^{-}-\mathrm{N}$ transport in the leachate, provided the model parameters and other input data are available. These validation results also revealed that the SWAP-ANIMO model could predict $\mathrm{NO}_{3}{ }^{-}-\mathrm{N}$ leaching very well for the area under study for rice and wheat crops.

The long-term model predictions depicted peaks of $\mathrm{NO}_{3}{ }^{-}-\mathrm{N}$ concentrations in leachate during December and January (Figure 7). The magnitude and maxima of $\mathrm{NO}_{3}{ }^{-}-\mathrm{N}$ fluxes in groundwater almost reached a steady state after the first year and then periodically repeated each year with a maximum flux value of $14 \mathrm{mg} \mathrm{kg}^{-1}$. Jiang et al. [34] observed a steady-state condition of $\mathrm{NO}_{3}{ }^{-}-\mathrm{N}$ fluxes in their long-term simulation study using the LEACHN model to evaluate the effects of climate and $\mathrm{N}$ fertilization under potato crop. The observed $\mathrm{NO}_{3}{ }^{-}-\mathrm{N}$ concentration peak in the winter can be seen in Figure 7. The leaching of $\mathrm{NO}_{3}{ }^{-}-\mathrm{N}$ load peaks corresponds to the rainfall events and irrigation applied during this time, which occur as the soil becomes saturated, allowing the unused $\mathrm{NO}_{3}{ }^{-}-\mathrm{N}$ from the previous crop to leach down. The predictions about $\mathrm{NO}_{3}{ }^{-} \mathrm{N}$ status in the ground water made through model simulations are in line with the present status in the Punjab [35].

The long-term model predictions revealed that if the amount of residual $\mathrm{N}$ in the soil profile at harvest of rice can be reduced, less $\mathrm{NO}_{3}{ }^{-}-\mathrm{N}$ will be leached. In the paddy fields, increasing the number of fertilizer applications and adjusting the amount of each fertilizer dose may be a viable method to reduce $\mathrm{NO}_{3}{ }^{-}-\mathrm{N}$ leaching and sustain the rice-wheat cropping system without a further contamination of groundwater resources. Another possible alternative is to either reduce the total amount of irrigation or increase irrigation frequency but maintain the total amount [31]. This approach brings the root zone to the field capacity for more time with the same amount of irrigation but has less water available to drain freely out of the root zone. Bawatharani et al. [36] found higher rates of irrigation coupled with higher application rates of fertilizer- $\mathrm{N}$ increase $\mathrm{NO}_{3}{ }^{-}-\mathrm{N}$ concentration at lower depths in sandy Regosols. They suggested that $\mathrm{N}$ fertilizer applications be recommended with the appropriate irrigation rates to minimize $\mathrm{NO}_{3}{ }^{-}-\mathrm{N}$ leaching in coarse-textured soils due to their high permeability. Ünlü et al. [37] also suggested that applying fertilizer at the end of irrigation instead of at the beginning can significantly reduce $\mathrm{N}$ leaching in very permeable sandy soils. The current study area is located in a flood plain with predominantly permeable sandy soils. The suggestions given above can also help solve the $\mathrm{NO}_{3}{ }^{-}-\mathrm{N}$ leaching 
problem in the winter season. During the last decade, simple and inexpensive leaf color charts for guiding field-specific fertilizer $\mathrm{N}$ doses are increasingly being adopted by farmers [38]. These improvements in fertilizer $\mathrm{N}$ management are leading to the application of fertilizer $\mathrm{N}$ as per the need of the crop so that losses via $\mathrm{NO}_{3}{ }^{-}-\mathrm{N}$ leaching are minimal.

\section{Conclusions}

The spatial variability of $\mathrm{NO}_{3}{ }^{-}-\mathrm{N}$ concentrations in groundwater was assessed on a regional scale by integrating the SWAP-ANIMO model with the GIS software. Thirty farm fields under annual rice-wheat cropping system in the Machhiwara block situated along the Satluj River in northwestern India were selected to study the $\mathrm{NO}_{3}{ }^{-}-\mathrm{N}$ transport in agricultural leachate. The average temporal variation of $\mathrm{NO}_{3}{ }^{-}-\mathrm{N}$ concentration in leachate show that the $\mathrm{NO}_{3}{ }^{-}-\mathrm{N}$ content was above the critical limit of $10 \mathrm{mg} \mathrm{kg}^{-1}$ by the end of December when the wheat crop is in the field. However, for the rest of the growing season, $\mathrm{NO}_{3}{ }^{-}-\mathrm{N}$ concentrations in the leachate in most areas were below the critical limit. The predictions using the SWAP-ANIMO model were validated by comparing soil moisture and $\mathrm{NO}_{3}{ }^{-}-\mathrm{N}$ distribution profiles of five sampling sites. A good correlation between the measured and predicted soil moisture values and $\mathrm{NO}_{3}{ }^{-}-\mathrm{N}$ concentrations were observed at all five sites. The Wilcoxon statistical test of measured versus predicted values indicated the mean differences for soil moisture content and $\mathrm{NO}_{3}{ }^{-}-\mathrm{N}$ concentration across the soil profiles were non-significant at a 5\% confidence level. Satisfactory results from the validation process indicate that the model could be further applied to compute $\mathrm{NO}_{3}{ }^{-}-\mathrm{N}$ leaching load in groundwater in a rice-wheat cropping system. The $\mathrm{NO}_{3}{ }^{-}-\mathrm{N}$ concentrations of leachate up to the year 2015 and exceeded the critical limit every year during December. The kriging mean $\mathrm{NO}_{3}{ }^{-}-\mathrm{N}$ concentrations of leachate up to 2015 were $4.9 \mathrm{mg} \mathrm{kg}{ }^{-1}$, which is within the safe limit. To reduce $\mathrm{NO}_{3}{ }^{-}-\mathrm{N}$ leaching in winter, the fertilizer- $\mathrm{N}$ rate, the application, and timing of the $\mathrm{N}$ application should be appropriately managed along with irrigation practices. A continuation of the same agricultural practices can cause a steady-state condition of $\mathrm{N}$ distribution in the soil-plant system. Thus, it would be advisable to change the agricultural practices after a few years and grow crops with high $\mathrm{N}$ removal efficiency. Although the modeling approach adopted in this study was satisfactory in assessing $\mathrm{NO}_{3}{ }^{-}-\mathrm{N}$ pollution in groundwater at a regional scale under a rice-wheat cropping system, it is complex as it requires many physical, chemical, and biological parameters to simulate field conditions.

Author Contributions: Conceptualization, B.S.F. methodology, B.S.F., P.-S. and B.-S.; software, B.S.F.; validation, B.S.F., P.-S. and B.-S.; formal analysis, B.S.F.; investigation, B.S.F. and P.-S.; resources, B.S.F., P.-S. and B.-S.; data curation, B.S.F., P.-S. and B.-S.; writing-original draft preparation, B.S.F.; writing-review and editing, B.S.F., P.-S. and B.-S.; visualization, B.S.F., P.-S. and B.-S.; supervision, B.S.F.; project administration, B.S.F.; funding acquisition, B.S.F. and B.-S. All authors have read and agreed to the published version of the manuscript.

Funding: This work is supported by the USDA National Institute of Food and Agriculture [Hatch project, SC-1700593].

Acknowledgments: The authors thank Punjab Remote Sensing Centre, Ludhiana, India, for providing lab facility and Geographical Information System and the Alterra Green World Research Centre for providing the ANIMO and SWAP models used in this study. The lead author also thanks Department of Soil and Water Engineering, Punjab Agricultural University to provide facilities to conduct this research degree.

Conflicts of Interest: The authors declare no conflict of interest.

\section{References}

1. Grover, D.K.; Singh, J.M.; Kaur, A.; Kumar, S. State Agricultural Profile—Punjab; Punjab Agricultural University: Ludhiana, Punjab, India, 2017; pp. 1-74.

2. Bijay-Singh; Varinderpal-Singh. Productivity and fertility of soils in the Indo-Gangetic Plains of South Asia. Arch. Agron. Soil Sci. 2012, 58, S33-S40. [CrossRef] 
3. Katyal, J.C.; Bijay-Singh; Vlek, P.L.G.; Buresh, R.J. Efficient Nitrogen Use as Affected by Urea Application and Irrigation Sequence1. Soil Sci. Soc. Am. J. 1987, 51, 366-370. [CrossRef]

4. Bijay-Singh; Yadvinder-Singh; Sekhon, G.S. Fertilizer-N use efficiency and nitrate pollution of groundwater in developing countries. J. Contam. Hydrol. 1995, 20, 167-184. [CrossRef]

5. Bhardwaj, A.; Garg, S.; Sondhi, S.K.; Taneja, D.S. Nitrate contamination of shallow aquifer groundwater in the central dis-tricts of Punjab, India. J. Environ. Sci. Eng. 2012, 54, 90-97. [PubMed]

6. Ahada, C.P.S.; Suthar, S. Groundwater nitrate contamination and associated human health risk assessment in southern districts of Punjab, India. Environ. Sci. Pollut. Res. 2018, 25, 25336-25347. [CrossRef] [PubMed]

7. Chhabra, A.; Manjunath, K.; Panigrahy, S. Non-point source pollution in Indian agriculture: Estimation of nitrogen losses from rice crop using remote sensing and GIS. Int. J. Appl. Earth Obs. Geoinf. 2010, 12, 190-200. [CrossRef]

8. Wick, K.; Heumesser, C.; Schmid, E. Groundwater nitrate contamination: Factors and indicators. J. Environ. Manag. 2012, 111, 178-186. [CrossRef]

9. $\quad$ van Dam, J.C.; Huygen, J.; Wesseling, J.G.; Feddes, R.A.; Kabat, P.; van Walsum, P.E.V.; Groenendijk, P.; van Diepen, C.A. Theory of SWAP Version 2.0. Simulation of Water Flow, Solute Transport and Plant Growth in the Soil-Water-Atmosphere-Plant Environment; Wageningen Agricultural University : Wageningen, The Netherlands, 1997; Volume 45, pp. 1-168.

10. Kroes, J.G.; Roelsma, J. ANIMO 3.5; User's Guide for the ANIMO Version 3.5 Nutrient Leaching Model; Wageningen Agricultural University: Wageningen, The Netherlands, 1997; Volume 46, pp. 1-100.

11. Asseng, S.; Keating, B.; Fillery, I.; Gregory, P.; Bowden, J.; Turner, N.; Palta, J.; Abrecht, D. Performance of the APSIM-wheat model in Western Australia. Field Crop. Res. 1998, 57, 163-179. [CrossRef]

12. Quemada, M.; Cabrera, M.L. CERES-N Model Predictions of Nitrogen Mineralized from Cover Crop Residues. Soil Sci. Soc. Am. J. 1995, 59, 1059-1065. [CrossRef]

13. Hansen, S.; Jensen, H.E.; Nielsen, N.E.; Svendsen, H. Simulation of nitrogen dynamics and biomass production in winter wheat using the Danish simulation model DAISY. Nutr. Cycl. Agroecosystems 1991, 27, 245-259. [CrossRef]

14. de Paz, J.M.; Ramos, C. Simulation of nitrate leaching for different nitrogen fertilization rates in a region of Valencia (Spain) using a GIS-GLEAMS system. Agric. Ecosyst. Environ. 2004, 103, 59-73. [CrossRef]

15. Jabro, J.D.; Toth, J.D.; Dou, Z.; Fox, R.H.; Fritton, D.D. Evaluation of Nitrogen Version of Leachm for Predicting Nitrate Leaching. Soil Sci. 1995, 160, 209-217. [CrossRef]

16. Li, Z.; Wen, X.; Hu, C.; Li, X.; Li, S.; Zhang, X.; Hu, B. Regional simulation of nitrate leaching potential from winter wheat-summer maize rotation croplands on the North China Plain using the NLEAP-GIS model. Agric. Ecosyst. Environ. 2020, $294,106861$. [CrossRef]

17. Duwig, C.; Normand, B.; Vauclin, M.; Vachaud, G.; Green, S.R.; Becquer, T. Evaluation of the WAVE Model for Predicting Nitrate Leaching for Two Contrasted Soil and Climate Conditions. Vadose Zone J. 2003, 2, 76-89. [CrossRef]

18. Wu, L.; McGechan, M. A Review of Carbon and Nitrogen Processes in Four Soil Nitrogen Dynamics Models. J. Agric. Eng. Res. 1998, 69, 279-305. [CrossRef]

19. Kroes, J.; Roelsma, J. Simulation of water and nitrogen flows on field scale; application of the SWAP-ANIMO model for the Müncheberg data set. In Modelling Water and Nutrient Dynamics in Soil-Crop Systems; Springer Science and Business Media LLC: Berlin/Heidelberg, Germany, 2007; pp. 111-128. [CrossRef]

20. Marinov, D.; Querner, E.; Roelsma, J. Simulation of water flow and nitrogen transport for a Bulgarian experimental plot using SWAP and ANIMO models. J. Contam. Hydrol. 2005, 77, 145-164. [CrossRef] [PubMed]

21. Kaufmann, V.; Pinheiro, A.; Castro, N.M.D.R. Simulating transport of nitrogen and phosphorus in a Cambisol after natural and simulated intense rainfall. J. Contam. Hydrol. 2014, 160, 53-64. [CrossRef] [PubMed]

22. Wolf, J.; Broeke, M.H.-T.; Rötter, R. Simulation of nitrogen leaching in sandy soils in The Netherlands with the ANIMO model and the integrated modelling system STONE. Agric. Ecosyst. Environ. 2005, 105, 523-540. [CrossRef]

23. Roelsma, J.; Hendriks, R. Comparative study of nitrate leaching models on a regional scale. Sci. Total. Environ. 2014, 499, 481-496. [CrossRef]

24. Li, H.; Wang, L.; Qiu, J.; Li, C.; Gao, M.; Gao, C. Calibration of DNDC model for nitrate leaching from an intensively cultivated region of Northern China. Geoderma 2014, 223-225, 108-118. [CrossRef]

25. Bijay-Singh; Yadvinder-Singh; Imas, P.; Xie, J.-C. Potassium Nutrition of the Rice-Wheat Cropping System. Adv. Agron. 2003, 81, 203-259. [CrossRef]

26. Farmaha, B.S. Evaluating Animo Model for Predicting Nitrogen Leaching in Rice and Wheat. Arid. Land Res. Manag. 2013, 28, 25-35. [CrossRef]

27. Cockx, L.; Van Meirvenne, M.; Hofman, G. Characterization of nitrogen dynamics in a pasture soil by electromagnetic induction. Biol. Fertil. Soils 2005, 42, 24-30. [CrossRef]

28. Panhwar, Q.A.; Ali, A.; Naher, U.A.; Memon, M.Y. Fertilizer Management Strategies for Enhancing Nutrient Use Efficiency and Sustainable Wheat Production. In Organic Farming: Global Perspectives and Methods; Elsevier BV: Amsterdam, The Netherlands, 2019; pp. 17-39. [CrossRef]

29. Wijayanti, Y.; Budihardjo, K.; Sakamoto, Y.; Setyandito, O. Topsoil N-budget model in orchard farming to evaluate groundwater nitrate contamination. IOP Conf. Ser. Earth Environ. Sci. 2017, 109, 12034. [CrossRef] 
30. Xue, Y.; Song, J.; Zhang, Y.; Kong, F.; Wen, M.; Zhang, G. Nitrate Pollution and Preliminary Source Identification of Surface Water in a Semi-Arid River Basin, Using Isotopic and Hydrochemical Approaches. Water 2016, 8, 328. [CrossRef]

31. El-Sadek, A.; Feyen, J.; Radwan, M.; El Quosy, D. Modeling water discharge and nitrate leaching using DRAINMOD-GIS technology at small catchment scale. Irrig. Drain. 2003, 52, 363-381. [CrossRef]

32. Delin, S.; Stenberg, M. Effect of nitrogen fertilization on nitrate leaching in relation to grain yield response on loamy sand in Sweden. Eur. J. Agron. 2014, 52, 291-296. [CrossRef]

33. Singh, K.; Sondhi, S. SW-Soil and Water: Validation of a Fertilizer Nitrogen Model during Crop Production. J. Agric. Eng. Res. 2001, 78, 317-324. [CrossRef]

34. Jiang, Y.; Zebarth, B.; Love, J. Long-term simulations of nitrate leaching from potato production systems in Prince Edward Island, Canada. Nutr. Cycl. Agroecosyst. 2011, 91, 307-325. [CrossRef]

35. Bijay-Singh; Craswell, E. Fertilizers and nitrate pollution of surface and ground water: An increasingly pervasive global problem. SN Appl. Sci. 2021, 3, 1-24. [CrossRef]

36. Bawatharani, T.; Mowjood, M.I.M.; Dayawansa, N.D.K.; Kumaragamage, D. Nitrate leaching as a function of fertilization and irrigation practices in sandy regosols. Trop. Agric. Res. 2004, 16, 172-180.

37. Ünlü, K.; Özenirler, G.; Yurteri, C. Nitrogen fertilizer leaching from cropped and irrigated sandy soil in Central Turkey. Eur. J. Soil Sci. 1999, 50, 609-620. [CrossRef]

38. Bijay-Singh; Varinderpal-Singh; Ali, A.M. Site-Specific Fertilizer Nitrogen Management in Cereals in South Asia. Sustain. Agric. Rev. 2020, 39, 137-178. [CrossRef] 